\title{
EFFECTS OF DRIED FRUIT PRESSING SUPPLEMENTS TO FAT- -ENRICHED FEED MIXTURES FOR FEEDLOT PIGS
}

\author{
L. NAJMAN, M. TOULOVÁ and E. MINKSOVÁ \\ Department of Animal Nutrition, University of Veterinary Science, 61242 Brno, \\ Veterinary Research Institute, 62132 Brno
}

Received August 24, 1981

\begin{abstract}
Najman L., M. Toulová, E. Minksová: Effect of Dried Fruit Pressing Supplements to Fat-Enriched Feed Mixtures for Feedlot Pigs. Acta vet. Brno, 50, 1981 : 191 - 199.

An experimental study of the effects of feeding dried grape or apple pressings was made in 100 pigs, Large White-Landrace cross, divided into five well-balanced groups of 20 animals. Replacement of 10 per cent of the basal feed mixture (complete feed mixture A 1 supplemented with $50 \mathrm{~g}$ rendering-plant fat per $\mathrm{kg}$ ) with an equal proportion of grape or apple pressings had a beneficial effect on body mass gain and feed consumption per kg gain of feedlot pigs. The relative decrease in alpha-tocopherol content of the feed mixtures during 5-month storage was lower in those containing fruit pressings than in that enriched merely with rendering-plant fat. The inclusion of rendering-plant fat in complete feed mixture A 1 produced a decrease in vitamin $\mathrm{E}$ concentration of the liver and in vitamin $\mathrm{A}$ and $\mathrm{E}$ concentration of the blood plasma of pigs. The fruit pressing supplements to the feed mixture enriched with rendering-plant fat were effective in controlling the decrease in the concentrations of the two vitamins. The serum aspartate aminotransferase and alanine aminotransferase activities were unaffected by the feed mixtures employed. The results indicate a beneficial effect of fruit pressing supplements on substance metabolism of feedlot pigs.
\end{abstract}

Health status, performance, dried white and red grape pressings, apple pressings, vitamin $E$, vitamin $A$, serum aspartate aminotransferase and alanine aminotransferase.

Supplementation of pig rations with various fats has been the subject of several studies and was reported to result in increased gain in body mass and improved feed conversion (Najman 1965; Zedník 1974; Phillips and Ewan 1977; a. o.). The advantage of replacing a proportion of fodder grains with fat has become particularly apparent in recent years with the increasing prices of grain and maize at the world market. On the other hand, fat supplementation of the ration is responsible for increased production of adipose tissue and increased fat content of the muscles, the extent of which is influenced by the type of animal (Moser 1978).

The evidence from a number of studies and from our own experiments has shown that feeding oxidized fats results in increased vitamin E requirements of the animals (L'Estrange et al. 1967; Connoly et al. 1970; Privett and Cortesi 1972; Najman et al. 1970; Najman et al. 1976). Moreover, the diet fed in intensive feeding units is generally high in crude protein and energy, which means a further increase in the requirements of vitamin E. High production makes considerable demands on the metabolism of the animals. Under such conditions it is necessary to add vitamin E supplements even to feed whose vitamin E content would be satisfactory for less heavily producing animals (Levina 1974; Menke 1974; Jenkins and Hidiroglou 1972; a. o.). By adding vitamin $\mathrm{E}$ to a feed mixture enriched with fat of various kind and of varying degree of rancidity it is possible to prevent health disorders of the animals and possibly also a reduction in their performance ( $\mathrm{Najman}$ et al. 1976; Najman 1976).

The object of the present study was to supplement fat-enriched feed mixtures not with synthetic tocopherol, but with natural vitamin $\mathrm{E}$ contained in some nontraditional feeds of plant origin such as grape and apple pressings, which are waste products of food-stuff industry (Toulová et al. 1977). 
Grape and apple pressings are dried and ground to a fine meal. When used in the original state, they have not the proper nutritional effect, because the nutrients which are contained mainly in the pips pass through the digestive tract and cannot be utilized (Kaliský 1976; Bykov 1976; Martos 1977). Arutjunjan (1970) and Agababjan (1974), e. g., recommended that fruit pressings should be fed to pigs because of their high crude protein and mineral content. Agababjan and Dobrickij (1976) who fed grape and apple pressing to feedlot pigs reported a saving in grains, a shorter fattening period and higher gains in body mass. Blair (1975), Herzig et al. (1979) and Najman et al. (1970) found that fruit pressings included in the diet to replace part of the feed ration for pigs were advantageous in terms of cost and involved no health hazards. An important observation with regard to sound human nutrition is the finding of reduced fat and increased protein content in the muscles of pigs fed a feed mixture supplemented with grape pressings (Toulová et al. 1979).

One of the factors that can explain the beneficial effect of fruit pressing on animal performance is their tocopherol content. There is evidence to indicate that grains, seeds and pips contain a considerable quantity of tocopherols and possibly other substances with specific synergic action (Young et al. 1975; Najman et al. 1980). Tocopherols and other natural antioxidants are contained mainly in grape and apple pips and protect substances subject to oxidative destruction both in vitro and in vivo (Lang 1970). This finding could be used to advantage mainly in the nutrition of monogastric farm animals that are fed fat-enriched rations.

\section{Materials and Methods}

The experiment involved 100 pigs, Large White-Landrace cross, divided into five well-balanced groups of 20 animals. At the beginning of the experiment the mean body mass in each group was $21 \mathrm{~kg}$. The experiment lasted 152 days. Group 1 animals were fed feed mixture A 1, a complete feed mixture, throughout the fattening period. Group 2 received the same feed mixture supplemented with $50 \mathrm{~g}$ rendering-plant fat per $\mathrm{kg}$ feed mixture. Groups 3, 4 and 5 were fed the same diet as Group 2 except that 10 per cent of it was replaced with an equal proportion of dried white grape pressings, red grape pressings and apple pressings, respectively. These fruit pressings consisted of all dried and ground waste left from the pressing of the fruit.

The feed mixtures were offered in self-feeders throughout the experiment. Water was available ad libitum from waterers. The animals were weighed at regular intervals and their body mass, feed consumption per animal per day and feed consumption per $\mathrm{kg}$ gain were recorded. The groups were loose housed in separate pens without bedding in one barn.

The feed mixtures were prepared at one time and were stored in the storage room of a co-operative farm where the experiment was conducted from December to May. Samples of the fat-enriched feed mixtures (diets fed to Groups 2, 3, 4 and 5) were taken at monthly intervals for alpha-tocopherol determination.

Major nutrient and ash content of the fruit pressings and feed mixtures was determined according to the Czechoslovak Standard CSN No. 467007 (1966), alpha-tocopherol content was determined according to Bieri (1969) using homogenization and saponification of the samples as described by Müller - Mullot (1972). Total sugar was determined according to Luff and Schoorl (Davídek et al. 1977). Blood and livers for biochemical examination were collected at slaughter at the end of the experiment. Vitamin A and E levels of the liver and blood plasma were determined by the method of Thompson et al. (1971, 1973). Serum aspartate aminotransferase (GOT) and alanine aminotransferase (GPT) activities were determined according to Reitman and Frankel (Hořejši 1964). The statistical significance of the results was assessed by Student's t-test. The results are tabulated as arithmetic means \pm standard deviations.

\section{Results}

The nutrient, alpha-tocopherol and total sugar content of the dried white and red grape pressings and apple pressings fed to the experimental animals is shown in Table 1. Red grape pressings had a lower fat content and substantially lower total sugar content than white grape pressings. Apple pressings equalled grape pressing as to nutrient content but were higher in alpha-tocopherol. There was little diference in major nutrient content between the feed mixtures containing the three kinds of fruit pressings (Table 2).

The stability of alpha-tocopherol in the fat-enriched feed mixtures with and 
Table 1

Nutrient and alpha-tocopherol content of dried fruit pressings ( $/ \mathbf{k g})$

\begin{tabular}{|c|c|c|c|}
\hline \multirow{2}{*}{ Component } & \multicolumn{2}{|c|}{ Grape pressings } & \multirow{2}{*}{ Apple pressings } \\
\hline & white & red & \\
\hline $\begin{array}{l}\text { Dry matter } \\
\text { Crude protein }(\mathrm{N} \times 6.25) \\
\text { Fat } \\
\text { Fibre } \\
\text { Ash } \\
\text { Alpha-tocopherol }(\mu \mathrm{mol} / \mathrm{kg}) \\
\text { Total sugar }\end{array}$ & $\begin{array}{r}935.2 \\
124.5 \\
79.6 \\
222.2 \\
56.4 \\
91.8 \\
38.2\end{array}$ & $\begin{array}{r}940.8 \\
123.4 \\
65.2 \\
211.3 \\
58.3 \\
98.6 \\
6.3\end{array}$ & $\begin{array}{r}927.1 \\
67.8 \\
41.4 \\
161.8 \\
18.2 \\
109.7 \\
45.3\end{array}$ \\
\hline
\end{tabular}

Table 2

Major nutrient and ash content of the feed mixtures employed (g/kg)

\begin{tabular}{|c|c|c|c|c|c|}
\hline & & & & \\
Group & Dry matter & Crude protein & Fat & Fibre & Ash \\
\hline & & & & \\
1 & & 164.2 & 21.8 & 27.3 & 28.2 \\
3 & 885.4 & 164.3 & 70.7 & 27.5 & 28.3 \\
4 & 888.7 & 161.3 & 77.9 & 40.8 & 34.9 \\
5 & 894.5 & 161.5 & 80.2 & 51.2 & 35.8 \\
\hline
\end{tabular}

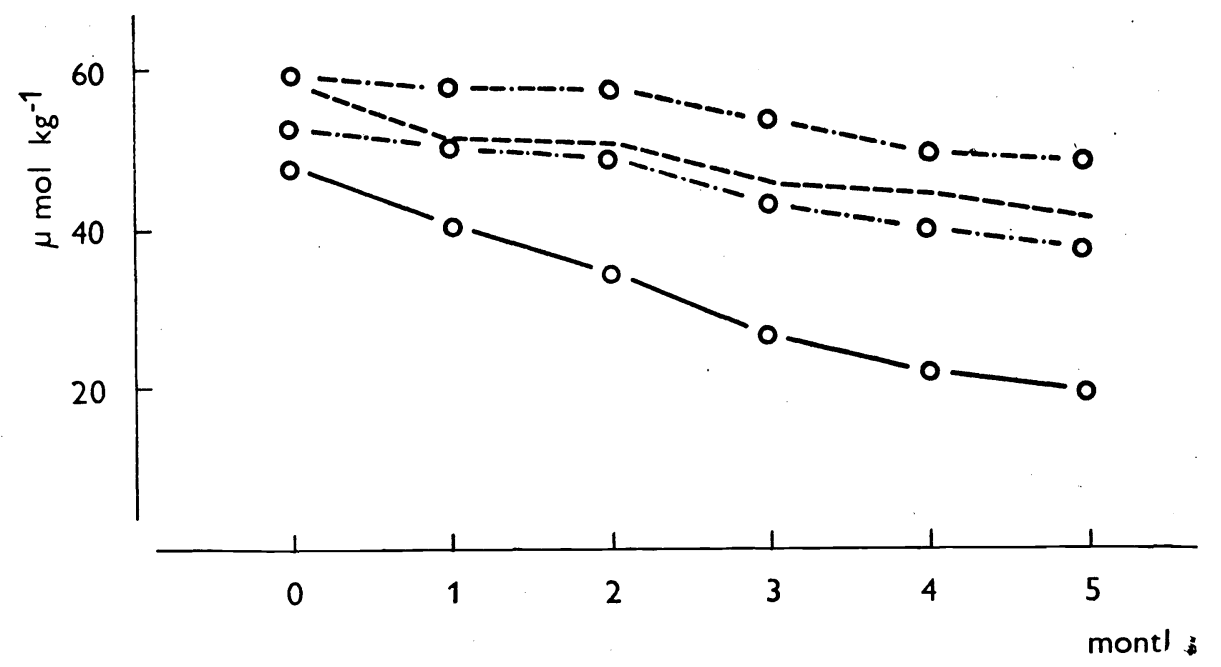

Fig. 1. Alpha-tocopherol content of the feed mixtures during storage

$\mathrm{O}-\mathrm{O}$ Feed mixture enriched with $50 \mathrm{~g} / \mathrm{kg}$ of rendering-plant fat

$\bigcirc---\bigcirc$ Same feed mixture as that indicated by $\bigcirc-O$ except that 10 per cent of it was replaced with white grape pressings

$\bigcirc-\cdot-\cdot \bigcirc$ Same feed mixture as that indicated by $\bigcirc-\bigcirc$ except that 10 per cent of it was replaced with red grape pressings

$0 \cdot--\cdot \bigcirc$ Same feed mixture as that indicated by $\bigcirc-\bigcirc$ except that 10 per cent of it was replaced with apple pressings 
without fruit pressings was followed during the 5-month storage on the farm. The rendering-plant fat used in this study was of average quality; its acid number was $21.50 \mathrm{mg} \mathrm{KOH} / \mathrm{g}$ fat, the peroxide value computed according to Wheeler was $6.15 \mathrm{ml}$ of $\mathrm{Na}_{2} \mathrm{~S}_{2} \mathrm{O}_{3}(\mathrm{c}=1 \mathrm{~mol} / \mathrm{l})$ per $\mathrm{kg}$ fat and the TBA value as determined according to Sedláček and Rybín (1957) was 0.415. The results show (Fig. 1) that the relative decreases in tocopherol content of the feed mixtures enriched with this fat were lower in those containing fruit pressings. At the end of the observation period the feed mixture not supplemented with fruit pressings contained 41.6 per

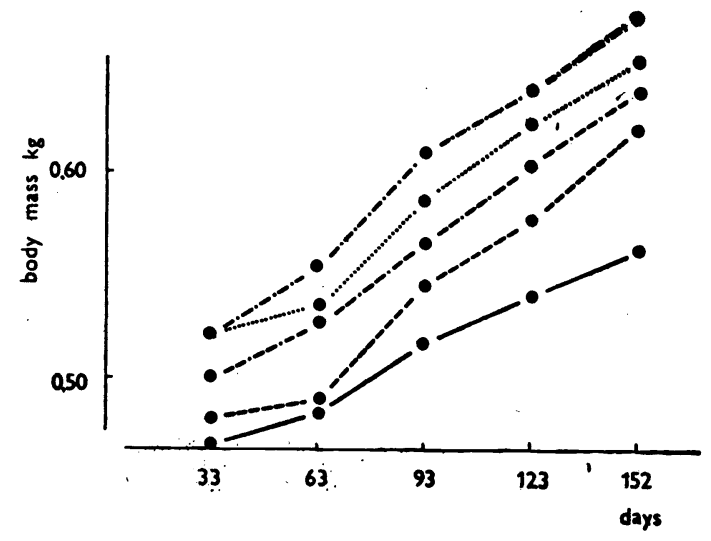
cent of its original alpha-tocopherol content, whereas the feed mixtures with fruit pressings contained 60 to 80 per cent of their original alpha-tocopherol content.

Fig. 2. Gains in body mass per animal per day (closed circles)

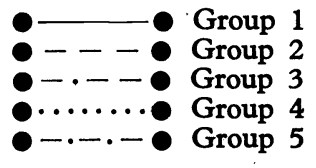

The pigs were placed on their respective diets immediately after they were transferred from the farrowing house without previous adaptation to the diet. They readily consumed the diets and became adapted to them without signs of any disturbances.

The feeding experiment lasted 152 days. At its end the three groups fed fruit pressing supplements were higher in mean body mass than Group 2 animals placed on the fat-enriched diet without fruit pressings; in Groups 3 and 5 the difference as against Group 2 was significant. A similar situation existed with regard to feed consumption per $\mathrm{kg}$ gain and feed consumption per animal per day (Table 3). Similarly, the daily gains in body mass per animal were highest in Group 3 fed white grape pressings followed by Group 5 fed apple pressings (Fig. 2).

Table 3

Rody mass of the pigs and their feed consumption

\begin{tabular}{|c|c|c|c|c|c|}
\hline Group & 1 & 2 & 3 & 4 & 5 \\
\hline $\begin{array}{l}\text { Start body mass } \\
\text { Body mass on day } 152 \\
\text { Average daily gain }(\mathrm{kg}) \\
\text { Feed consumption per } \mathrm{kg} \\
\text { gain }(\mathrm{kg}) \\
\text { Feed consumption per } \\
\text { animal per day }(\mathrm{kg})\end{array}$ & $\begin{array}{c}21.5 \pm 2.25 \\
109.5 \mathrm{a} \pm 9.25 \\
0.57 \\
3.75 \\
2.17\end{array}$ & $\begin{array}{c}21.3 \pm 1.87 \\
115.9 \pm 8.25 \\
0.61 \\
3.43 \\
2.13\end{array}$ & $\begin{array}{c}21.5 \pm 2.52 \\
126.1 b \pm 10.47 \\
0.68 \\
3.03 \\
2.08\end{array}$ & $\begin{array}{c}22.0 \pm 2.35 \\
119.1 \pm 9.78 \\
0.63 \\
3.51 \\
1.20\end{array}$ & $\begin{aligned} & 21.4 \pm 1.95 \\
& 122.2 \mathrm{a} \pm 10.12 \\
& 0.66 \\
& 3.12 \\
& 2.07\end{aligned}$ \\
\hline
\end{tabular}

a Significant $(P<0.05)$ difference as against Group 2.

b Significant $(P<0.01)$ difference as against Group 2 . 
Table 4

Vitamin $\mathbf{E}$ and $\mathbf{A}$ content of the liver and blood plasma ef experimental pigs (Means \pm S. D.)

\begin{tabular}{|c|c|c|c|}
\hline Group & $\underset{(\mu \mathrm{mol} / \mathrm{g})}{\text { Vitamin } \mathrm{E} \text { in the liver }}$ & $\begin{array}{l}\text { Vitamin } \mathrm{E} \text { in the blood plasma } \\
(\mu \mathrm{mol} / 1)\end{array}$ & $\begin{array}{c}\text { Vitamin } \mathrm{A} \text { in the blood plasma } \\
(\mu \mathrm{mol} / 1)\end{array}$ \\
\hline $\begin{array}{l}1 \\
2 \\
3 \\
4 \\
5\end{array}$ & $\begin{array}{l}15.91 \pm 9.11 \\
10.57 \pm 4.40 \\
19.41 \mathrm{c} \pm 4.10 \\
16.77 \mathrm{c} \pm 2.87 \\
18.58 \mathrm{c} \pm 5.45\end{array}$ & $\begin{array}{c}10.76 a \pm 2.34 \\
8.75 \pm 0.99 \\
10.80 \pm 3.25 \\
10.83 \pm 3.14 \\
11.49 a \pm 3.57\end{array}$ & $\begin{array}{l}1.20 \mathrm{a} \pm 0.16 \\
0.97 \pm 0.22 \\
1.34 \mathrm{~b} \pm 0.30 \\
1.16 \mathrm{a} \pm 0.12 \\
1.40 \mathrm{c} \pm 0.23\end{array}$ \\
\hline
\end{tabular}

a Significant $(P<0.05)$ difference as against Group 2.

b Significant $(P<0.01)$ difference as against Group 2 .

c Significant $(P<0.001)$ difference as against Group 2.

Table 5

GOT and GPT activities in the blood serum (Means + S. D.)

\begin{tabular}{|c|c|c|}
\hline Group & $\begin{array}{c}\text { GOT } \\
(\mathrm{U} / 1)\end{array}$ & $\begin{array}{c}\text { GPT } \\
\text { (U/1) }\end{array}$ \\
\hline 1 & $18.00 \pm 3.17$ & $23.84 \pm 2.84 t$ \\
2 & $20.50 \pm 3.50$ & $25.17 \pm 5.50 t$ \\
3 & $18.67 \pm 2.00$ & $25.00 \pm 2.17$ \\
4 & $17.00 \pm 3.90$ & $21.17 \pm 5.00 t$ \\
& $19.84 \pm 5.17$ & $22.67 \pm 4.83 t$ \\
\hline
\end{tabular}

Ten per cent grape and apple pressing supplements to the fat-enriched feed mixtures in Groups 3, 4 and 5 produced a highly significant rise in vitamin $\mathrm{E}$ level of the liver as compared with Group 2 (Table 4). Group 2 animals, which were fed the fat-containing diet without fruit pressing supplements, had the lowest vitamin $\mathrm{E}$ concentration in both the liver and the blood plasma. The decrease in the plasma level of vitamin $\mathrm{E}$ was significant as against Group 1. The concentration of vitamin $E$ in both the liver and the plasma of animals fed fruit pressing supplements (Groups 3, 4 and 5) exceeded that of Groups 2, with the difference for the liver being invariably significant, and even that of Group 1 fed the basal complete diet without fat and fruit pressing supplements.

The lowest blood plasma concentration of vitamin A was found in Group 2 fed the fat-enriched ration without fruit pressing supplements. This decrease was significant as against Group 1 . The three groups fed the ration supplemented with fruit pressings had vitamin A concentration in the blood plasma significantly higher than Group 2. The highest blood plasma vitamin A concentration was found in Group 5, i. e. in pigs fed apple pressing supplements. The aspartate aminotransferase and alanine aminotransferase activities were apparently unaffected by the diets employed (Table 5).

\section{Discussion}

The nutrient and ash content of the fruit pressings was in keeping with the data reported by other writers (R ůžička and Bendl 1976; Lízal and Šrámek 1976; Herzig et al. 1979; a. o.). 
Our results as to the effects of storage on the feed mixtures containing rendering-plant fat and fruit pressings are in harmony with the findings in other studies (Herzig et al. 1977; Najman et al. 1980) in that the biological value of fat-enriched feed mixtures supplemented with tocopherol-containing fruit pressings is after 6 months' storage superior to that of a feed mixture containing no fruit pressing supplements. The growth-promoting effect of dried grape and apple pressings included in the diet for fattening pigs supports the observations of Agababjan et al. (1974), Agababjan and Dobrickij (1976), Blair (1975), Herzig et al. (1979) and others who regarded fruit pressings as a suitable feed also for pigs. The fact that the growth-promoting effect of red grape pressings was smaller than that of white grape pressings can be accounted for by their lower fat and sugar content in connexion with the current technology of red wine production. A certain role can be attributed also to their higher content of tannin (Farkaš 1973). The inclusion of gruit pressings in the feed mixtures resulted among other things in their increased fibre content, an advantage in view of the fact hat Czechoslovak feed mixtures for pigs are frequently low in fibre (Výmola and Blahou tová 1978). Moreover, the evidence provided by Pond and Kass (1977) suggests that pigs tolerate rather high fibre levels without being affected in their body mass gain provided that a satisfactory energy level of the ration is secured by a sufficient grain or fat supply, which was the case in our experiment.

A major role in the beneficial effect of feed mixtures containing fruit pressings can be ascribed, no doubt, to their tocopherol level which is nutritionally important and increases the biological value of the feed mixtures. Tocopherol contributes to stabilization of the fat component of feed mixtures which may be subject to oxidation as demonstrated in a previous study (Toulová et al. 1977). Another merit of feed mixtures containing fruit pressings is their higher content of fat and sugar which increase the supply of energy.

The levels of tocopherol in the blood plasma and liver of our experimental pigs suggest that the effect of grape and apple pressing supplements to fat-enriched feed mixtures compares favourably with that of synthetic alpha-tocopherol supplements as reported in our previous studies ( $\mathrm{Naj}$ man et al. 1976; Najman 1976). It is well established in fact that tocopherol requirements of monogastric animals increase if their ration contains replacement fats of a certain degree of rancidity (Shadrin 1975; Marthedal 1973; a. o.). In the present experiment where the feed mixture containing rendering-plant fat was supplemented with natural components containing native tocopherol, the concentration of tocopherol in the liver and blood plasma did increase. As to the securation of pigs with vitamin A, our results point out that feeding rendering-plant fat to pigs reduces their concentration of vitamin A in the blood plasma. Fruit pressing supplements, however, obviate this danger. Although they do not contain vitamin A, they were found to contain carotenes (Toulová et al. 1977). Moreover, vitamin E supports absorption of carotenes, increases their utilization and influences the efficiency of conversion to vitamin A. Vitamin $\mathrm{E}$ acts synergically with vitamin A and their combined presence in the body improves the performance and health status of the animals (Kudriavceva 1974). The serum aspartate aminotransferase and alanine aminotransterase activities were unaffected by the feeding mixtures employed, an observation that suggests damage to the tissues (Sova 1972). Similarly, pigs fed a ration containing fruit pressings without fat supplements showed no changes in biochemical indicators of the blood that would make this non-traditional feed appear unsuitable (Toulová et al. 1979). 
The performance of the experimental animals and the concentration of vitamins $\mathrm{A}$ and $\mathrm{E}$ in their tissues suggest that feeding fruit pressings has a marked beneficial effect on substance metabolism of the pig.

\section{Účinnost sušených ovocných výlisků $v$ tukovaných krmných směsích pro výkrm prasat}

Do pokusu bylo zařazeno 100 prasat, křiženců plemene bílé ušlechtilé a landrase, rozdělených do 5 vyrovnaných skupin po 20 zvíratech. Náhrada $10 \%$ základní krmné směsi (kompletní krmná směs A $1 \mathrm{~s}$ přídavkem $50 \mathrm{~g}$ kafilerniho tuku k $1 \mathrm{~kg}$ navic) stejnými podíly sušených výlisků hroznových nebo jablečných, významně pozitivně ovlivnila př́růstky hmotnosti prasat ve výkrmu i spotřebu krmiva na $1 \mathrm{~kg}$ prírůstku hmotnosti. Relativní úbytky obsahu alfa-tokoferolu v krmných směsích byly po 5 měsících skladováni menši ve směsích s ovocnými výlisky, než ve směsi pouze s tukem. Zařazení kafilerního tuku ke kompletní krmné směsi A 1 vyvolalo pokles koncentrací vitamínu $\mathrm{E} v$ játrech a vitamínu $\mathrm{A}$ i $\mathrm{E}$ v krevní plazmě prasat. Přídavky výliskủ ke směsi s tukem pokles koncentrací vitamínů úspěšně tlumily. Aktivity sérových aminotransferáz asparagátu a alaninu nebyly ovlivněny použitými krmnými směsmi. Dosažené výsledky svědčí o pozitivním působení přídavku ovocných výlisků na látkový metabolismus prasat ve výkrmu.

\section{Эффективность сушеных фруктовых отходов в жировых кормовых смесях для откорма свиней}

В әксперимент было включено 100 свиней; помеси белой породистой и ландрас, разделенных на пять равных групп по двадцать животных. Замещение $10 \%$ основной кормовой смеси (комплектная смесь А 1 с добавлением $50 \mathrm{r}$ жира к 1 кг) одинаковой долей сушеных отходов винограда или яблок оказало существенное положительное влияние на прирост массы свиней в откорме и на расход кормов на 1 кг прироста массы. Относительная убыль содержания альфа-токоферола в смесях с сушеными фруктовыми отходами балы спустя 5 месяцев складирования меньше по сравнению со смесью с жиром. Включение жира в комплектную кормовую смесь А 1 вызывало понижение концентраций витамина $\mathrm{E}$ в печени и витамина $\mathrm{A}$ и $\mathrm{E}$ в сыворотке крови поросят. Добавление сушеных фруктовых отходов к смеси с жиром понижение концентрации витаминов успешно притормозили. Используемые кормовые смеси не оказали влияния на активности сывороточных аминотрансфераз аспарагата и аланина: Достигнутые результаты свидетельствуют о положительном воздействии добавки Фруктовых отходов на метаболизм свиней в откорме.

\section{References}

AGABABJAN, R. D. - DOBRICKIJ, J.: Otchody vinnych, plodovoovoščnych i koževenych zavodov - korm dlja svinej. Životnovodstvo, 1, 1976: 50-51.

AGABABJAN, R. D. - IGRASHEV, I. - DOBRICKIJ, J.: Chimičeskij sostav nepiččevych otchodov. Svinovodstvo, 6, 1974: 22.

ARUTJUNJAN, B. L.: Vinogradnyje vyžimky v kormlenii svinej. Svinovodstvo, 5, 1970: 10-11.

BIERI, J. G.: Chromatography of tocopherols. In: Lipid chromatographic analysis. New York, 1969. 
BLAIR, R.: Utilizing wastes in animal feeds - an European overview. Feedstuffs, 26, 1975: $33-34$.

BYKOV, V.: Korm iz vinogradnych i jabločnych vyžimok. Korma, 1, 1976: 44-45.

CONNOLY, J. F. - SPILANE, T. A. - POOLE, D. B. - McALEESE, D. M.: Nutritional effects of oxidized lipids in fresh and stored pig diets. Irish J. Agric., Res., 9, 1970: 39-58.

DAVÍEEK, J. - HRDLIČKA, J. - KARVÁNEK, M. - POKORNÝ, J. - SEIFERT, J. VELÍSEK, J.: Laboratorní přiručka analýzy potravin. Praha 1977.

FARKAŠ, B.: Technologie a biochemie vina. SZNP Praha, 1973.

HERZIG, I. - TOULOVÁ, M. - HOLUB, A. - PLESKAČ, Z.: Uplatnění sušených hroznových výlisků u prasat ve výkrmu. Vet. Med., Praha, 24, 1979: 705-713.

HOŘJJŚ, J.: Základy chemického vyšetřování v lékařství. Praha 1964.

JENKINS, K. J. - HIDIROGLOU, M.: A review of selenium vitamin E responsive problems in livestock: a case for selenium as a food additive in Canada. J. Anim. Sci., 51, 1971: 237-240.

KALISKÝ, D.: Sušené hroznové výlisky. In: Kolektiv autorov: Tvarovaná krmiva. Bratislava 1976.

KUDRJAVCEVA, L. A.: Vitamin E i jego primenenie v životnovodstve i veterinarii. Sel. Choz. Rubež. Životnov., 5, 1977: 20-25.

LANG, K.: Biochemie der Ernáhrung. Darmstadt, 1970.

LEVINA, L.: Vitamin E v racionach porosjat. Svinovodstvo, 45, 1974: 24.

L'ESTRANGE, J. L. - CARPENTER, K. K. - LEA, C. H.: Nutritional effect of autoxidized fats in animal diets. 4. Performance of young pigs containing meat meals of high peroxide value. Br. J. Nutr., 21, 1967: 377-390.

LÍZAL, F. - ŠRÁMEK, J.: Výživná hodnota sušených výlisků jablečných, třešňových a hroznových pro skot. Živočišná Výroba, Praha, 21, 1976: 701-708.

MARTOS, L.: Borgazdasági melléktermékek felhasználása takarmanyozásra. Borgazdaság, 25, 1977: 113-115.

MARTHEDAL, H. E.: Encephalomalacia in chicks with special reference to frequency and the occurrence of pathological and anatomical changes. Acta Agric. Scand., 19, 1973: 58-63.

MENKE, K. H.: Aktuelle Probleme den Vitaminsversorgung beim Schwein. Bayer. Landwirtsch. Jb., 51, 1974: 244-251.

MOSER, B. D.: Animal fat in the finishing feed. Pig int., 8, 1978: 46-48.

MULLER-MULLOT, W.: Quantitative Bestimmung von Gesamt-alpha-tokopherol in Futter und Lebensmitteln, einschliesslich Öle und Fetten. Z. Lebensmittelunters. Forsch., 148, 1972: $201-206$.

NAJMAN, L. - ṠIKULA, M. - TOULOVÁ, J. - MINKSOVÁ, E. - ZÍMA, S. - VYSKOČILOVÁ, V. - INGR, I.: Netradični píce a obsah biologicky aktivních látek. (Project report) University of Veterinary Science, Brno, 1980.

NAJMAN, L.: Problematika použití tukủ do krmných směsí. Biologizace Chem. Výž. Zviŕ., 4, 1968: 283-284.

NAJMAN, L. - HERZIG, I. - TOULOVÁ, M. - INGR, I.: Možnost uplatnění kostního tuku ve výživě prasat. Vet. Med., Praha, 15, 1970: 731-740.

NAJMAN, L. - TOULOVÁ, M. - ČERNÁ, J. - URBANOVÁ, J.: The effect of dietary fats of different stages of oxidative rancidity on the development of vitamin $\mathrm{E}$ deficiency in pigs. Acta vet., Brno, 45, 1976: 23-30.

NAJMAN, L.: Vztah tukủ $\mathrm{v}$ dietě hospodářských zviřat se zřetelem $\mathrm{k}$ potřebě vitaminu $\mathrm{E}$ (Habilitation thesis) University of Veterinary Science, Brno, 1976.

PHILLIPS, B. C. - EWAN, R. C.: Utilisation of energy of milo and soybean oil by young swine. J. Anim. Sci., 44, 1977: 990-997.

POND, W. G. - KASS, M.: Higher fiber diets for swine. Cornell Nutrition Conference Proceedings, 1977: 133-138.

PRIVETT, O. S. - CORTESI, R.: Observations on the role vitamin E in the toxicity of oxidized fats. Lipids, 7, 1972: 780-787.

RƯŽIČKA, B. - BENDL, B.: Tabulky složení krmiva a koeficienty stravitelnosti. In: Kacerovský, O.: Nové směry ve výživě hospodářských zvířat. Praha, 1976.

SOVA, Z. et al.: Některé základní fyziologické hodnoty $\mathrm{v}$ krvi a játrech prasat různého věku (II.). Biologizace Chem. Výž. Zviŕ., 8, 1972: 159-166.

SHADRIN, N.: Techničeskij žir v racionach. Svinovodstvo, 45, 1974: 18-19.

THOMPSON, J. N. - ERDODY, P. - MURRAY, T.: Fluorometric determination of vitamin $A$ in human blood and liver. Biochem. Med., 5, 1971: 67-89.

THOMPSON, J. N. - ERDODY, P. - MAXWELL, W. B.: Simultaneous fluorometric determination of vitamin $A$ and $E$ in human serum and plasma. Biochem. Med., 8, 1973: 403-414.

TOULOVÁ, M. - HERZIG, I. - NAJMAN, L.: Antioxidační působení ovocných výliskủ a možnost jejich uplatnění ve výživě hospodářských zviŕat. Biologizace. Chem. Výž. Zvír., 13, 1977: $277-281$. 
TOULOVÁ, M. - HERZIG, I. - DVOǨ́K, M. - VOJTÍŠEK, B. - RASZYK, J.: Změny biochemických ukazatelú krve a orgánú prasat při podávání sušených hroznových výliskú. Vet. Med., Praha, 24, 1979: 715-724.

VÝMOLA, J. - BLAHOUTOVÁ, V.: Produkční účinnost krmných směsí pro prasata $\mathrm{v}$ roce 1977. Krmivářství, 14, 1978: $79-80$.

YOUNG, L. G. - LUN, A. - POS, J. - FORSHAW, R. P. - EDMEADES, D.: Vitamin E stability in corn and mixed feed. J. Anim. Sci., 40, 1975: 495-499.

ZEDNIK, M.: Použití tukủ ve výkrmu prasat. Krmivářství a Služby, 10, 1974: 57-60.

Czechoslovak Standard ČNN 46 7007. Výživná hodnota krmiv. 1966. 